\title{
Editorial
}

Ophthalmic
Research

\section{Angiogenesis in Uveal Melanoma}

\author{
Martine J. Jager \\ Department of Ophthalmology, Leiden University Medical Center, Leiden, The Netherlands
}

Uveal melanoma is the most frequently occurring malignancy in the adult eye. Over the last twenty years, improvement of local treatments has greatly contributed to better preservation of vision and the eye. New studies help to further preserve vision, as shown in the paper by Desjardins et al. [1] in this journal. Randomized studies as described in their paper are essential to improve treatment of the most difficult cases, but in general, much can be achieved already to preserve vision.

On the other hand, in spite of many basic research efforts and attempts to improve treatment of fatal liver metastases, survival after the development of metastases of uveal melanoma is still abysmal. Recently, a new research area has opened up which warrants a closer look. Over the last couple of years, an interest in the role of angiogenesis in the eye and in cancer has bloomed. The increase in knowledge of blood vessels has led to the development of a plethora of new anti-angiogenesis drugs, which can for instance be used as treatment of age-related macular degeneration and diabetic retinopathy [2]. It seems that, originally, interest for anti-angiogenesis agents derived from cancer research [3]. At the same time that the new drugs were under development, many people realized the importance of blood vessels in uveal melanoma with regard to tumour growth and the development of metastases.

\section{Blood Vessels and Primary Uveal Melanoma}

While blood vessels are an essential part of the eye, vessels growth is also essential in the development of tumours in the eye. Every clinician is aware of this: for over 50 years, fluorescence angiography has been used to detect abnormal vessel growth and vessel behaviour, which helps to differentiate a uveal malignant melanoma from a choroidal nevus. Any tumour larger than 1-2 mm needs additional vessels to supply oxygen, and similar to e.g. breast cancer, it is known that larger tumours have a higher blood vessel density $[4,5]$. Turning on the angiogenic switch is therefore an important part of the early development of uveal melanomas, which are known to produce a range of angiogenic factors $[6,7]$. The biochemical changes that are the basis of this switch are as yet unknown. However, recent studies that compared RNA expression between melanocytes or melanoma, or between primary tumours and metastases revealed an important role for angiogenic factors in tumour progression $[8-11]$.

\section{Blood Vessels and Metastases}

Blood vessels are essential in the process of metastases formation. Several studies have shown that the presence of a high local vascular density in uveal melanomas is associated with worse survival, as is ingrowth of tumour cells into the lumen of tumour blood vessels and into the sclera $[5,12,13]$. This is a logical finding, as tumour cells

Dr. M.J. Jager

Department of Ophthalmology

PO Box 9600

NL-2300 RC Leiden (The Netherlands)

Tel. +31 71526 3097, Fax +31 71524 8222, E-Mail m.j.jager@lumc.nl 
need to invade blood vessels in order to get into the circulation and then spread to other sites in the body. In addition, the presence of extravascular matrix or 'Folberg patterns', which are considered to be fluid-conducting networks, has been found to be associated with a bad prognosis [14]. As erythrocytes have been identified inside the networks, it can be assumed that tumour cells may also use this route to migrate from the eye.

Blood vessels are necessary to support the growth of metastases in distant organs, such as the liver. Vessel density in liver metastases shows a similar pattern as in primary tumours [15]. Furthermore, blood vessels also play a role in treatment. After local treatment of uveal melanomas by irradiation, radiation retinopathy often develops. This is considered to be a micro-angiopathy similar to diabetic retinopathy, with ischemia, macular oedema and new vessel proliferation. The newly developed antiangiogenesis agents may help to prevent or treat vessel leakage and new vessel proliferation in this disease.

\section{Blocking Vessel Development}

In all of these situations, new anti-angiogenic drugs may play a role. While the first studies on the application of drugs for treatment of radiation retinopathy are being reported [16], using anti-angiogenesis drugs in the treatment of the primary tumour is still in the laboratory phase. It is known that uveal melanomas and uveal melanoma cell lines produce factors like VEGF and angiopoietin-1 and $-2[6,17]$, which are known to stimulate vessel growth, an essential requirement for tumour enlargement. Inhibition of factors like VEGF may therefore contribute to inhibition of further tumour growth. Experimental studies on the behaviour of tumours after inhibition of vessel formation are already being performed in animal models. A very nice example is the study by Ozerdem [18], as reported in this issue of Ophthalmic Research. Uveal melanoma xenografts were grown in the eyes of normal wild type mice, as well as in mice knocked out for the NG2 gene (Nerve/Glial antigen 2). The NG2 proteoglycan is an essential part of pericytes. Developing vessels not only need endothelial cells but also pericytes to strengthen the vessel wall, and mice that lack the NG2 gene have previously been shown to have a reduced capacity to form vessels in the cornea or the retina after specific stimuli [19]. Ozerdem [18] implanted uvea melanoma cells in the suprachoroidal space of eyes of NG2knockout mice and normal mice and analyzed tumour growth 2 weeks after implantation. Microvascular den- sity was determined by confocal microscopy, looking for vessels stained by monoclonal antibody. Tumours that developed in NG2-knockout mice remained much smaller (95\% smaller) and showed almost $44 \%$ less vessels than the tumours in normal mice.

These findings indicate that (1) blood vessel growth is essential for uveal melanoma outgrowth in mice, and (2) that pericytes are an essential part of vessel formation in growing uveal melanomas in a murine model. This indicates that not only endothelial cells but also pericytes may be a potential treatment target in human uveal melanoma.

Inhibition of vessel growth may not only be relevant to treatment of the primary tumour, but may also be applied as adjuvant therapy to high-risk cases in order to prevent dormant liver metastases from developing into clinically significant lesions.

Combination therapies that attack the endothelial cells as well as the pericytes may be a future option.

\section{Conclusion}

Ozerdem's paper teaches us at least three lessons: the importance of blood vessels in the development of uveal melanoma, the relevance of pericytes in the tumour angiogenesis, and the usefulness of using a murine model to learn about intraocular tumours. With angiogenesis research, we hopefully have a promising new approach to treat uveal melanoma, its metastases and the complications of treatment. 


\section{References}

1 Desjardins L, Lumbroso-Le Rouic L, Levy C, Dendale R, Delacroix S, Nauraye C, Estève $\mathrm{M}$, Plancher C, Asselain B: Combined proton beam radiotherapy-transpupillary thermotherapy for large uveal melanomas: randomized study on 151 patients. Ophthalmic Res 2006;38:255-260.

2 Campochiaro PA and the First ARVO/Pfizer Institute Working Group: Ocular versus extraocular neovascularization: mirror images or vague resemblances. Invest Ophthalmol Vis Sci 2006;47:462-474.

3 Folkman J: Clinical applications of research on angiogenesis. N Engl J Med 1995;333: 1757-1763.

4 Weidner N, Semple JP, Welch WR, Folkman $\mathrm{J}$ : Tumor angiogenesis and metastasis - correlation in invasive breast carcinoma. $\mathrm{N} \mathrm{Engl}$ J Med 1991;324:1-8.

5 Makitie T, Summanen P, Tarkkanen A, Kivela $\mathrm{T}$ : Microvascular density in predicting survival of patients with choroidal and ciliary body melanoma. Invest Ophthalmol Vis Sci 1999;40:2471-2470.

6 IJland SAJ, Jager MJ, Heijdra BM, Westphal JR, Peek R: Expression of angiogenic and immunosuppressive factors by uveal melanoma cell lines. Melanoma Res 1999;9:445-450.

7 Boyd SR, Tan D, Bunce C, Gittos A, Neale $\mathrm{MH}$, Hungerford JL, Charnock-Jones S, Cree IA: Vascular endothelial growth factor is elevated in ocular fluids of eyes harbouring uveal melanoma: identification of a potential therapeutic window. Br J Ophthalmol 2002; $86: 448-452$.
8 Zuidervaart W, van der Velden PA, Hurks $\mathrm{MH}$, van Nieuwpoort FA, Out-Luiting CJ, Singh AD, Frants RR, Jager MJ, Gruis NA: Gene expression profiling identifies tumour markers potentially playing a role in uveal melanoma development. Br J Cancer 2003; 89:1914-1919.

9 Van der Velden PA, Zuidervaart W, Hurks $\mathrm{MH}$, Pavey S, Ksander BR, Krijgsman E, Frants RR, Tensen CP, Willemze R, Jager MJ, Gruis NA: Expression profiling reveals that methylation of TIMP3 is involved in uveal melanoma development. Int J Cancer 2003; 106:472-479.

10 Nareyeck G, Zeschnigk M, von der Haar D, Schilling H, Bornfeld N, Anastassiou G: Differential expression of tissue inhibitor of matrix metalloproteinases 3 in uveal melanoma. Ophthalmic Res 2005;37:23-28.

11 Ehlers JP, Harbour JW: Molecular pathobiology of uveal melanoma. Int Ophthalmol Clin 2006;46:167-180.

12 Overkleeft EN, Zuidervaart W, Hurks HM, Eilers PH, de Wolff-Rouendaal D, Jager MJ: Prognostic value of disodium phosphate 32P uptake test in uveal melanoma: a long-term study. Arch Ophthalmol 2003;121:1398.
13 Foss AJE, Alexander RA, Jefferies LW, et al: Microvessel count predicts survival in uveal melanoma. Cancer Res 1996;56:2900-2903.

14 Folberg R, Rummelt V, Parys-van Ginderdeuren R, Hwang T, Woolson RF, Pe'er J, Gruman LM: The prognostic value of tumor blood vessel morphology in primary uveal melanoma. Ophthalmology 1993;100:13891398.

15 Toivonen P, Makitie T, Kivela T: Microvessels and macrophages in choroidal and ciliary body melanoma; in Jager MJ, Niederkorn JY, Ksander BR (ed): Uveal Melanoma: A Model for Exploring Fundamental Cancer Biology. Abingdon, Taylor and Francis, 2004, pp 177-189.

16 Shields CL, Demirci H, Dai V, Marr BP, Mashayekhi A, Materin MA, Manquez ME, Shields JA: Intravitreal triamcinolone acetonide for radiation maculopathy after plaque radiotherapy for choroidal melanoma. Retina 2005;25:868-874.

17 Missotten GS, Notting IC, Schlingemann RO, Zijlmans HJ, Lau C, Eilers PHC, Keunen JEE, Jager MJ: Vascular endothelial growth factor-a in eyes with uveal melanoma. Arch Ophthalmol 2006, in press.

18 Ozerdem U, Stallcup WB: Pathological angiogenesis is reduced by targeting pericytes via the NG2 proteoglycan. Angiogenesis 2004;7:269-276.

19 Ozerdem U: Targeting pericytes diminishes neovascularisation in orthotopic uveal melanoma in NG2 proteoglycan knockout mouse. Ophthalmic Res 2006;38:251-254. 